Measurement of patient outcome in arthritis. Arthritis Rheum, 1980, 23, 137-145.

9. Smythe, H.A., Helewa, A., and Goldsmith, C.H. "Independent Assessor" and "Pooled Index" as techniques for measuring treatment effects in rheumatoid arthritis. J Rheumatol, 1977, 4, 144152.

10. Forrester, D.M., Neison, J.W. Abnormalities of the Cartilage Space. In: The Radiology of Joint Disease. Philadelphia, W.B. Saunders Co., 1973, 68-103.

11. Buckland-Wright, J.C. X-ray assessment of activity in rheumatoid disease. $\mathrm{Br} \mathrm{J}$ Rheumatol, 1981, 22, 3-10.

12. Bellamy, N., Newhook, L., Rooney, P.J., et al. Perception - A problem in the grading of sacro-iliac joint radiographs. Scand J Rheumatol 1984, 13, 113-120.

13. Mewa, A.A.M., Pui, M., Cockshott, W.P., et al. Observer differences in detecting erosions in radio- graphs of rheumatoid arthritis. A comparison of posteroanterior, Norgaard and Brewerton views. $J$ Rheumatol, 1983, 10 (2), 216-221.

14. Carmines, E.G., Zeller, R.A. Reliability and Validity Assessment. Beverly Hills : Sage Publications, 1979.

15. Meenan, R.F., Gertman, P.M., Mason, J.H., et al. The arthritis impact measurement scales. Further investigations of a health status measure. Arthritis Rheum, 1982, 25 (2), 1048-1053.

16. Huskisson, E.C. Measurement of pain. The Lancet. November 9, 1974, 1127-1130.

17. Ward, J.R., Niethammer, T.A., Egger, M.J. Can we just measure signal joints? Should ring size and walking time be analyzed only in selected patients? Controversies in the Clinical Evaluation of Analgesic-Anti-Inflammatory-Antirheumatic Drugs. Edited by H.E. Paulus, G.E. Ehrlich, E. Lindenlaub, New York, F.K. Schattauer Verlag, 1980.

\title{
ERRATUM :
}

We wish to call the attention of our readers to an omission in Clinical Rheumatology $7: 1,80-86,1988$. It should read as follows :

\section{Antinuclear antibodies in scleroderma, mixed connective tissue disease and "primary" Raynaud's phenomenon}

\author{
M. CRUZ, G. MEJIA, C. LAVALLE, J.J. CORTES*, \\ P.A. REYES*
}

Instituto Mexicano del Seguro Social, Hospital de Especialidades, Centro Médico, La Raza.

* Instituto Nacional de Cardiologia, Ignacio Chavez, Mexico, D.F., Mexico. 